\title{
Microstructural saturation, hardness stability and superplasticity in ultrafine-grained metals processed by a combination of severe plastic deformation techniques
}

\author{
S. Sabbaghianrad ${ }^{1 \dagger}$, T.G. Langdon ${ }^{1,2}$ \\ †ssabbagh@usc.edu
${ }^{1}$ Departments of Aerospace \& Mechanical Engineering and Materials Science, University of Southern California, Los Angeles, CA 90089-1453, U.S.A.
${ }^{2}$ Materials Research Group, Faculty of Engineering and the Environment, University of Southampton, Southampton SO17 1BJ, U.K.

\begin{abstract}
A commercial Al-7075 aluminum alloy was used to investigate the significance of the saturation hardness and saturation microstructure after processing by high-pressure torsion (HPT) through up to 20 turns or a combination of equal-channel angular pressing (ECAP) for 4 or 8 passes and HPT. The results show additional grain refinement by initially processing the material by ECAP to produce an ultrafine grain size before conducting the HPT. Thus, the grain size immediately prior to the HPT processing controls the saturation microstructure and hardness. Microstructural images reveal a significant grain refinement from elongated grains in the samples prior to processing with an average grain diameter of $\sim 8 \mu \mathrm{m}$ to equiaxed grains with an average grain size of $\sim 200 \mathrm{~nm}$ after processing by a combination of ECAP for 8 passes and HPT through 20 turns. This grain refinement leads to an improvement in the mechanical properties of the Al-7075 alloy. Vickers microhardness tests show a significant increase in the microhardness values of the Al-7075 alloy from $\mathrm{Hv} \approx 102$ in the annealed samples to $\mathrm{Hv} \approx 270$ after processing by a combination of ECAP for 8 passes and HPT through 20 turns. Specimens processed by a combination of ECAP and HPT also exhibit excellent superplastic properties with elongations up to $>1000 \%$ at $673 \mathrm{~K}$.
\end{abstract}

Keywords: aluminum 7075 alloy, equal-channel angular pressing, hardness, high-pressure torsion, severe plastic deformation, superplasticity

\section{Насыщение микроструктуры, стабильность твердости и сверхпластичность ультрамелкозернистых металлов, полученных комбинацией методов интенсивной пластической деформации}

\begin{abstract}
Промышленный алюминиевый сплав Al-7075 был использован для исследования степени насыщения твердости и насыщения микроструктуры после обработки путем кручения под высоким давлением (КВД) вплоть до 20 оборотов или комбинации равноканального углового прессования (РКУП) в 4 или 8 проходов и КВД. Результаты показывают, что имеет место дополнительное измельчение зерен при предварительной обработке материала путем РКУП, который создает ультрамелкозернистую структуру перед КВД. Таким образом, размер зерен непосредственно перед КВД определяет микроструктуру и твердость при насыщении. На микроструктурных изображениях выявляется значительное измельчение зерен, их преобразование от удлиненных зерен со средним диаметром около 8 мкм в образцах перед деформацией до равноосных зерен со средним размером около 200 нм после комбинации РКУП в 8 проходов и КВД в 20 оборотов. Это измельчение зерен приводит к улучшению механических свойств сплава Al-7075. Измерения микротвердости по Виккерсу показывают значительное повышение микротвердости сплава Al-7075 от Нv 102 в отожженных образцах до Нv 270 после обработки комбинацией РКУП в 8 проходов и КВД в 20 оборотов. Образцы, обработанные комбинацией РКУП и КВД, проявляют также отличные сверхпластические свойства с удлинениями до более чем $1000 \%$ при $673 \mathrm{~K}$.
\end{abstract}

Ключевые слова: алюминиевый сплав 7075, равноканальное угловое прессование, твердость, кручение под высоким давлением, интенсивная пластическая деформация, сверхпластичность 


\section{Introduction}

Metals with very small grain sizes are generally fairly strong because the yield stress at low temperatures is related to the reciprocal of the square root of the grain size through the Hall-Petch relationship [1,2]. Furthermore, superplastic behavior is expected at elevated temperatures in metals having very small grain sizes [3]. Recently, the processing of metals through the application of severe plastic deformation (SPD) has attracted much attention in materials science. Through these processing techniques it is possible to achieve ultrafine-grained (UFG) materials [4] which are defined as polycrystals having average grain sizes less than $1 \mu \mathrm{m}$ [5].

Several SPD processing methods are now available [6] but the two techniques receiving the most attention are equalchannel angular pressing (ECAP) [7] and high-pressure torsion (HPT) [8]. In ECAP the sample is in the form of a rod or bar and it is pressed repetitively through a die constrained within a channel that is bent internally through an abrupt angle. In processing by HPT the sample is generally in the form of a thin disk and it is held between two massive anvils and then subjected to an applied pressure and concurrent torsional straining [9-13]. Experimental results show that processing by HPT produces both smaller grain sizes and a higher fraction of grain boundaries having high-angles of misorientation than when processing using ECAP [14-16].

Processing by SPD techniques produces higher strength in materials which is demonstrated most effectively by taking individual readings of the Vickers microhardness, Hv, at selected positions on the polished surfaces of samples processed by either ECAP or HPT. Many reports have recorded measurements of Vickers microhardness on the cross-sectional planes [17-19] and the longitudinal planes [19-21] of ECAP samples and on the surfaces of disks processed by HPT [22-24].

At present the limits of grain refinement that may be attained through processing by ECAP or HPT $[25,26]$ remain unresolved. Accordingly, this paper examines whether there is a true limitation on the refining of grains when processing by HPT and experiments are described which are designed to provide a critical examination of the possible occurrence of a true refining limit.

\section{Experimental material and procedures}

A commercial aluminum-based Al-7075 alloy containing (in wt $\%$ ) $5.6 \% \mathrm{Zn}, 2.5 \% \mathrm{Mg}$ and $1.6 \% \mathrm{Cu}$ was used for these experiments. The alloy was received in the form of extruded rods with diameters of $10.0 \mathrm{~mm}$. These rods were cut into billets having lengths of $\sim 65 \mathrm{~mm}$ and then the billets were annealed in air at $753 \mathrm{~K}$ for $1 \mathrm{~h}$ and cooled to room temperature. In the annealed and unprocessed condition, the grains were elongated with lengths up to $\sim 450 \mu \mathrm{m}$ and widths of $\sim 8 \mu \mathrm{m}$. This alloy was processed by HPT and also by ECAP and a combination of ECAP and HPT. Earlier reports described the processing of the Al-7075 alloy by SPD techniques [27-29].

For ECAP, the processing was performed at $473 \mathrm{~K}$ using a solid die with a channel having an internal angle of $110^{\circ}$ and an outer arc of curvature of $20^{\circ}$. This geometry and these angles lead to an imposed strain of $\sim 0.8$ on each passage through the die [30]. The pressure was applied using a hydraulic press with a total capacity of 150 tonnes. Samples were processed using a pressing speed of $\sim 0.5 \mathrm{~mm} \mathrm{~s}^{-1}$ and processing route $\mathrm{B}_{\mathrm{C}}$ in which the billet is rotated by $90^{\circ}$ around the longitudinal axis in the same direction between each pass [31]. This processing route was selected because it leads to equiaxed ultrafine grains having high-angle grain boundaries as demonstrated in earlier results on pure aluminum [32].

Following ECAP through either 4 or 8 passes, disks were cut from some of the billets and then used for processing by HPT: these samples are henceforth designated the $\mathrm{ECAP}+\mathrm{HPT}$ samples. All HPT processing used disks with diameters of $10.0 \mathrm{~mm}$ and thicknesses of $\sim 0.83 \mathrm{~mm}$. The disks were polished prior to HPT and then processed at room temperature (RT) for selected numbers of revolutions, $N$, under an applied pressure of $6.0 \mathrm{GPa}$ and with a rotational rate of $1 \mathrm{rpm}$. The HPT facility used in this investigation imposed the pressure and concurrent torsional straining through two massive anvils. Both the upper and lower anvils were machined with spherical depressions at the centers of the adjacent surfaces with diameters of $10 \mathrm{~mm}$ and depths of $0.25 \mathrm{~mm}$. Each disk was placed in the depression on the lower anvil and the anvils were then brought together to impose a pressure on the disk. Torsional straining was achieved by rotation of the lower anvil at a constant speed of $1 \mathrm{rpm}$. The processing was conducted under quasi-constrained conditions in which there is a very small outflow of material around the perimeter of each disk during the processing operation $[33,34]$.

In this investigation the major emphasis was to evaluate the limits of grain refinement under different HPT processing conditions which was conducted experimentally through measurements of hardness saturation. Microhardness values relate directly to the microstructures in the materials. All values of the Vickers microhardness, Hv, were recorded using a microhardness tester equipped with a Vickers indenter using a load of $100 \mathrm{gf}$ and a dwell time of $15 \mathrm{~s}$ for each measurement. The individual hardness values were recorded from indentations along randomly selected diameters on the surfaces of each disk. The microhardness value for each indentation was obtained from the average of four separate hardness measurements recorded at uniformly separated points displaced around the selected position. The distance between each indentation was $0.3 \mathrm{~mm}$ and this was effectively reduced to 0.15 $\mathrm{mm}$ due to averaging the four points for each measurement.

The microstructural characteristics of the alloy were investigated for the samples processed by ECAP for 4 passes and 8 passes in the centers of the cross sections of the billets. These observations were made on the cross-sectional planes which correspond to the $X$ planes in the conventional notation for the orthogonal axes in ECAP [35]. Electron back-scatter diffraction (EBSD) and orientation imaging microscopy (OIM) were used to record these data. The microstructural data were obtained using an analytical field emission scanning electron microscope (SEM) JEOL JSM-7001F at an operating voltage of $15 \mathrm{kV}$.

High-angle grain boundaries (HAGBs) were defined by the software as boundaries having misorientation differences between adjacent measuring points of more than $15^{\circ}$ and low-angle grain boundaries (LAGBs) were defined as having misorientation differences of $2^{\circ}-15^{\circ}$. 
A sample processed by ECAP for 8 passes and HPT through a total of 20 turns was prepared by focused ion beam (FIB) for examination by transmission electron microscopy (TEM). The TEM thin foil was sectioned from the cross section (X plane) in the center of the disk. Specimens were processed by FIB under $30 \mathrm{kV}$ using gallium ion to a final thickness of $\sim 70 \mathrm{~nm}$. TEM was performed using a Philips CM12 microscope operating at $200 \mathrm{kV}$ for the sample processed by a combination of ECAP and HPT.

\section{Experimental results}

Figure 1 shows OIM images and the grain boundary misorientation distributions for the Al-7075 alloy near the center of the cross sectional plane of the billet processed by ECAP

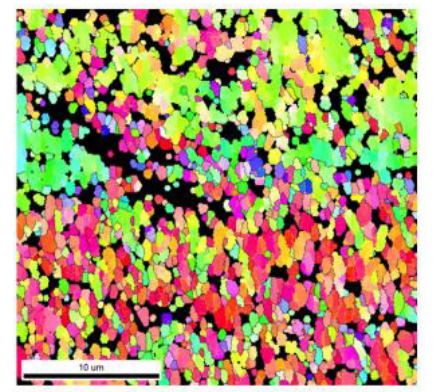

(a)

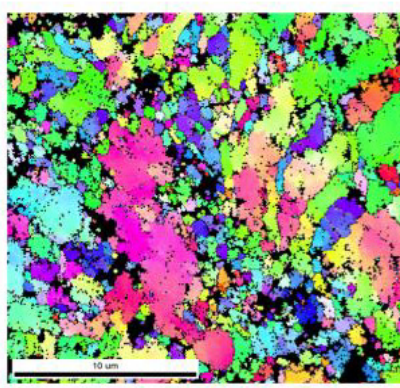

(b)
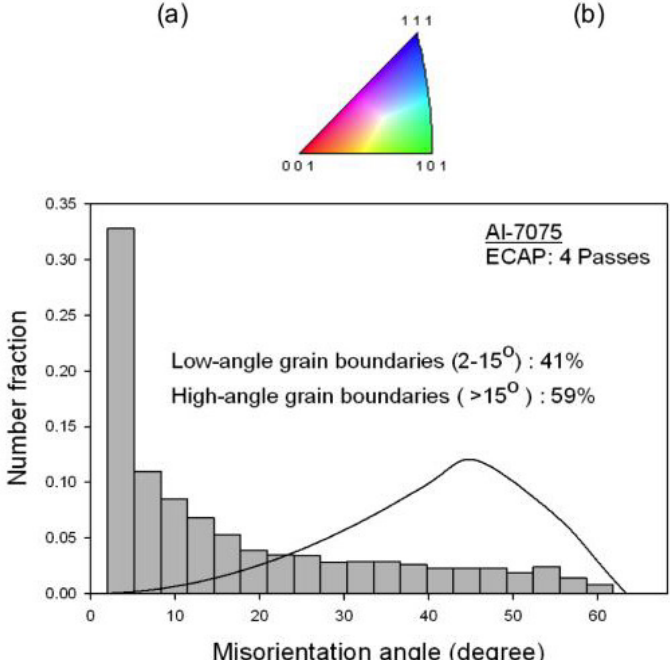

(c)

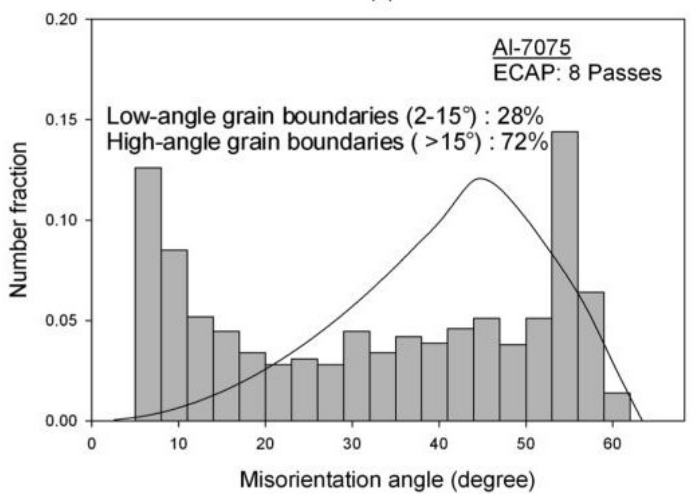

(d)

Fig. 1. Microstructure and number fraction of misorientation angles in the center of the disks cut from bars processed by ECAP for (a),(c) 4 passes, and (b),(d) 8 passes. for 4 passes and 8 passes: the grain misorientations in (a) and (b) are represented with different colors as depicted in the appropriate unit triangles. In the boundary misorientation distributions, HAGBs have misorientations of $15^{\circ}$ or more, LAGBs have misorientations between $2^{\circ}$ and $15^{\circ}$ and the solid curves shown in (c) and (d) represent the predicted theoretical distributions for a random array of misorientation angles [36,37].

Figure 1 shows that the number fractions of HAGBs increase with increasing numbers of ECAP passes. This value is increased from $\sim 59 \%$ after 4 passes in the center of the billet to $\sim 72 \%$ in the center of the billet after 8 passes. These fractions are in agreement to those reported earlier for high purity $\mathrm{Al}$ processed by ECAP through different numbers of passes [12]. It is apparent that the microstructure of the sample processed by ECAP for 8 passes is not homogeneous and it consists of grains of various sizes in both the central and edge regions of the billet. Nevertheless, there was a measured average grain size of $\sim 600 \mathrm{~nm}$ and this is smaller than the grain size of $\sim 680 \mathrm{~nm}$ reported earlier for a specimen processed by ECAP for only 4 passes [28]. Thus, it is concluded that there is continued but relatively minor grain refinement when processing by ECAP through 4 to 8 passes.

TEM images of the sample processed by ECAP for 8 passes and HPT through total numbers of 20 turns reveal an ultrafine equiaxed microstructure with an average grain size of $200 \mathrm{~nm}$. TEM images of the sample are illustrated in Fig. 2: (a) bright field image and (b) dark field image at the same position on the sample.

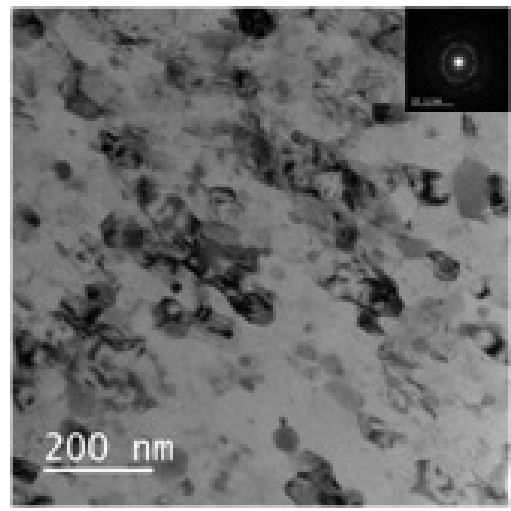

a

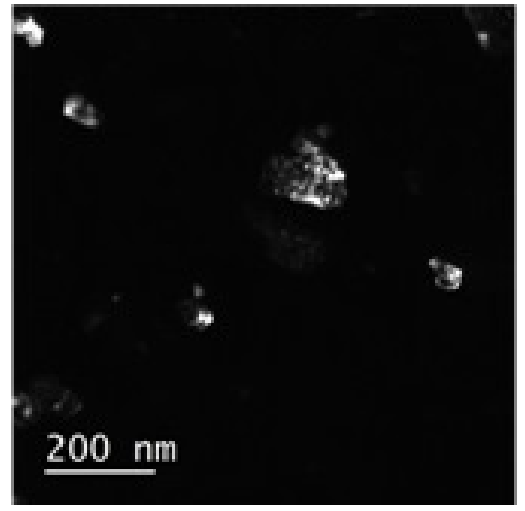

b

Fig. 2. TEM images of Al-7075 alloy processed by ECAP for 8 passes and HPT through total number of 20 turns: (a) bright field image and (b) dark field image of the same position. 


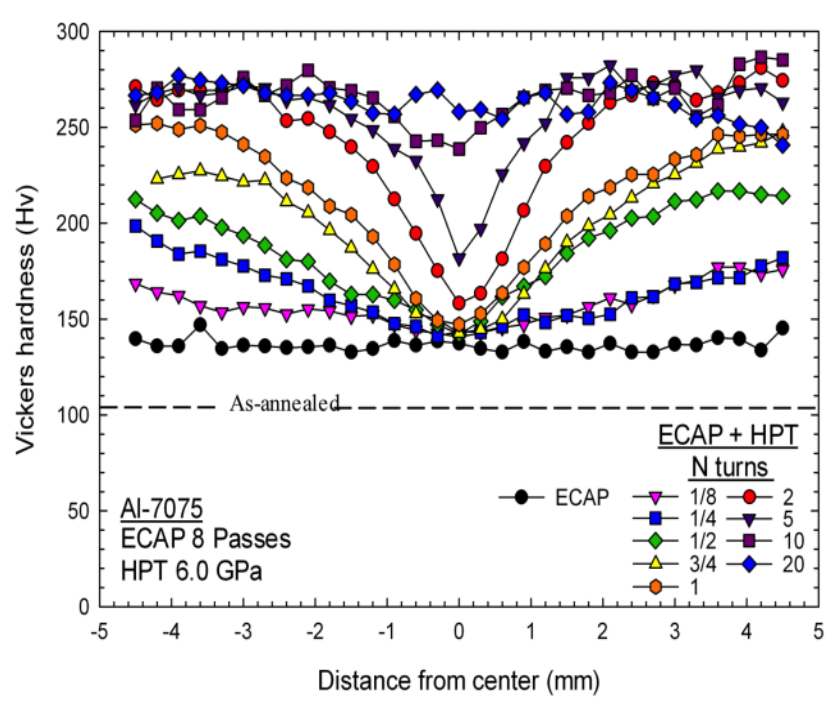

Fig. 3. Values of the Vickers microhardness plotted against the position on the diameters of disks processed by ECAP for 8 passes or by a combination of ECAP for 8 passes + HPT for up to 20 turns.

Earlier measurements showed that processing by HPT introduced significant grain refinement in the alloy. Thus, as described elsewhere [28], the average grain size in this alloy was $\sim 500 \mathrm{~nm}$ in the center of an HPT disk after processing by HPT for 5 turns but a significantly smaller grain size of $\sim 310 \mathrm{~nm}$ was recorded after processing by ECAP for 4 passes and then conducting additional processing by HPT through a total of 20 turns. The value of average grain size is reduced to $200 \mathrm{~nm}$ after processing by ECAP for 8 passes followed by HPT through a total number of 20 turns.

These results demonstrate that further grain refinement is achieved when the processing is continued to higher strains. Values of the Vickers microhardness were taken along randomly selected diameters of disks of the Al-7075 alloy processed by ECAP for 8 passes and then by HPT through various numbers of turns from $1 / 8$ to 20 using an applied pressure of 6.0 GPa. The results of these measurements are shown in Fig. 3 where the individual points are plotted against the distance from the center of the disk for each testing condition and with the lower dashed line showing the hardness value of $\mathrm{Hv} \approx 102$ in the alloy after annealing but prior to ECAP or HPT processing [27].

These results show that the microhardness values are essentially identical across the diameter of the disk after processing by ECAP for 8 passes and the microhardness values increase for the samples processed with ECAP + HPT and the increase becomes larger with increasing numbers of turns in the HPT processing. Initially, this increase occurs preferentially around the edge of the disk but the hardness values at the edges tend to stabilize after about 10 turns and the hardness appears to be reasonably saturated at all points across the disk.

Tensile tests were performed at a temperature of $623 \mathrm{~K}$ at initial strain rates of $1.0 \times 10^{-1}, 1.0 \times 10^{-2}$ and $1.0 \times 10^{-3} \mathrm{~s}^{-1}$ and the results for these three strain rates are shown in Fig. $4 \mathrm{a}, \mathrm{b}, \mathrm{c}$, respectively. For all strain rates, the samples processed using only ECAP for 8 passes show the highest values for the flow stresses whereas much lower stresses are consistently recorded after processing by ECAP for 8 passes plus HPT.

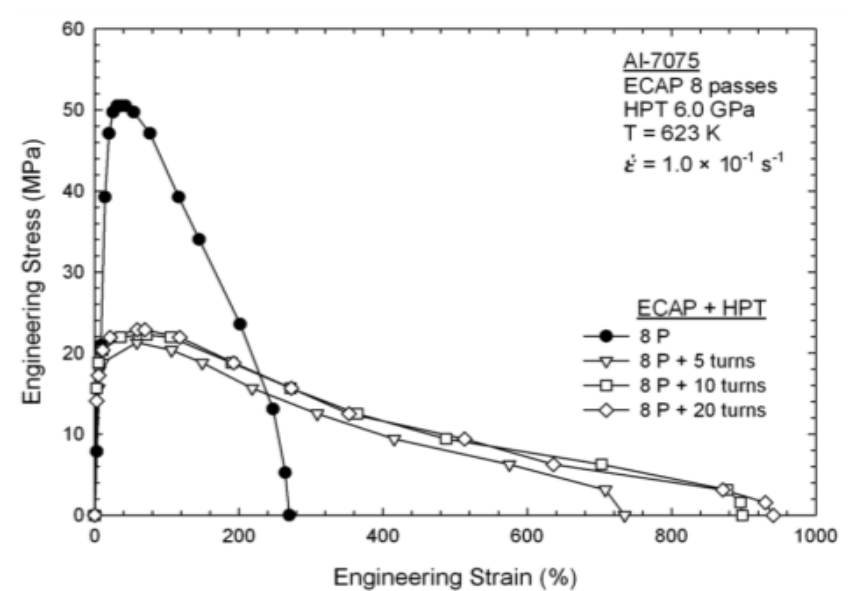

(a)

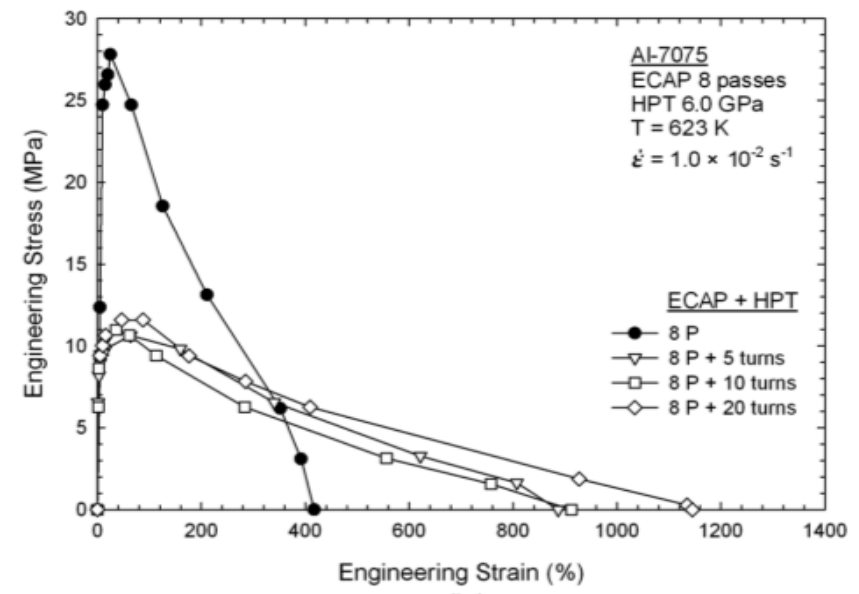

(b)

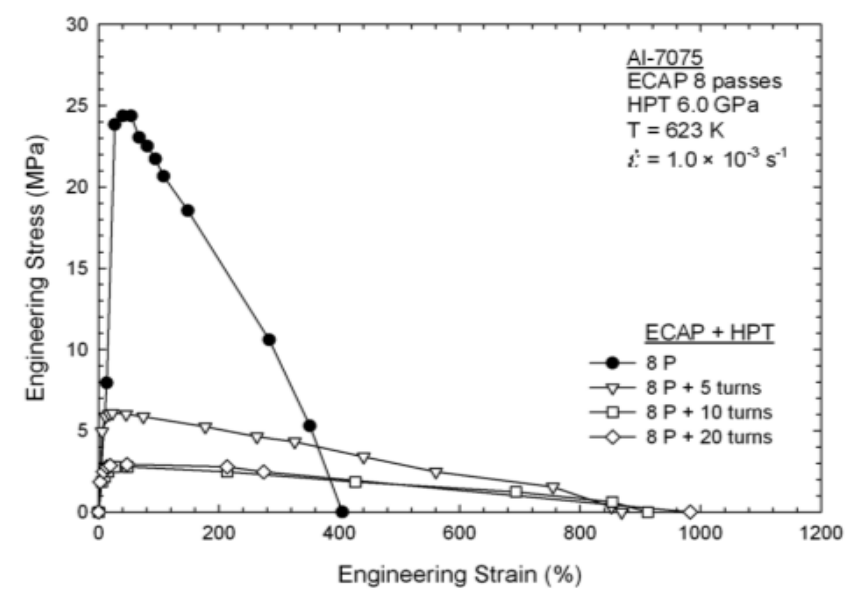

(c)

Fig. 4. Plots of engineering stress against engineering strain for specimens processed by ECAP for 8 passes and by ECAP for 8 passes plus HPT for up to 20 turns: samples were pulled to failure at $623 \mathrm{~K}$ at strain rates of (a) $1.0 \times 10^{-1} \mathrm{~s}^{-1}$, (b) $1.0 \times 10^{-2} \mathrm{~s}^{-1}$ and (c) $1.0 \times 10^{-3} \mathrm{~s}^{-1}$.

The elongations to failure after processing by a combination of ECAP and HPT reach a maximum of $~ 1100 \%$ in the sample processed by HPT through 20 turns at the strain rate of $1.0 \times 10^{-2} \mathrm{~s}^{-1}$ and this demonstrates excellent superplastic properties since superplasticity requires tensile elongations of at least $400 \%$ [38]. By contrast, the samples processed only by ECAP for 8 passes show maximum elongations of $\sim 400 \%$ which are on the limit of the true superplastic regime. 


\section{Discussion}

Processing by SPD techniques produces exceptional grain refinement. In general, processing by HPT is preferable to ECAP because it leads both to smaller grains and to higher fractions of high-angle grain boundaries. It is generally assumed that the factors influencing the saturation hardness attained in HPT are dependent upon the experimental processing conditions including the applied pressure in HPT, the temperature of processing and possibly upon the rate of rotation of the HPT anvil although experiments suggest this rate probably has only a relatively minor influence [39]. Recent studies have derived expressions for the minimum grain sizes obtained after processing by HPT or ECAP. Further inspection shows that these relationships incorporate some features related to the initial unprocessed condition such as the dislocation density and the yield stress [40,41]. However, there is no clear and definitive relationship that specifically dictates the saturation conditions that may be attained after a combination of processing by ECAP and HPT.

In the present investigation there is a clear difference between the saturation hardnesses that are achieved in the Al-7075 alloy after three different testing conditions. Figure 5 is a schematic illustration of the microhardness values of samples processed by HPT without any ECAP, by ECAP for 4 passes followed by HPT and by ECAP for 8 passes followed by HPT: the latter line is taken from Fig. 3 , the other lines are taken from earlier measurements $[27,28]$ and, for simplicity of presentation, the experimental points are not included in Fig. 5. For HPT with $P=6.0 \mathrm{GPa}$ the hardness saturates at $\mathrm{Hv} \approx 230$, for ECAP through 4 passes and then the same conditions for HPT there is a saturation at $\mathrm{Hv} \approx 250$ and for ECAP through 8 passes and then the same HPT there is a saturation at $\mathrm{Hv} \approx 270$.

It is readily apparent that all points for the HPT samples have the lowest values and the points for the ECAP+HPT disks show higher values of Hv. This is in agreement with the plot of hardness values against number of turns of HPT processing. By noting that the numbers of hardness mea-

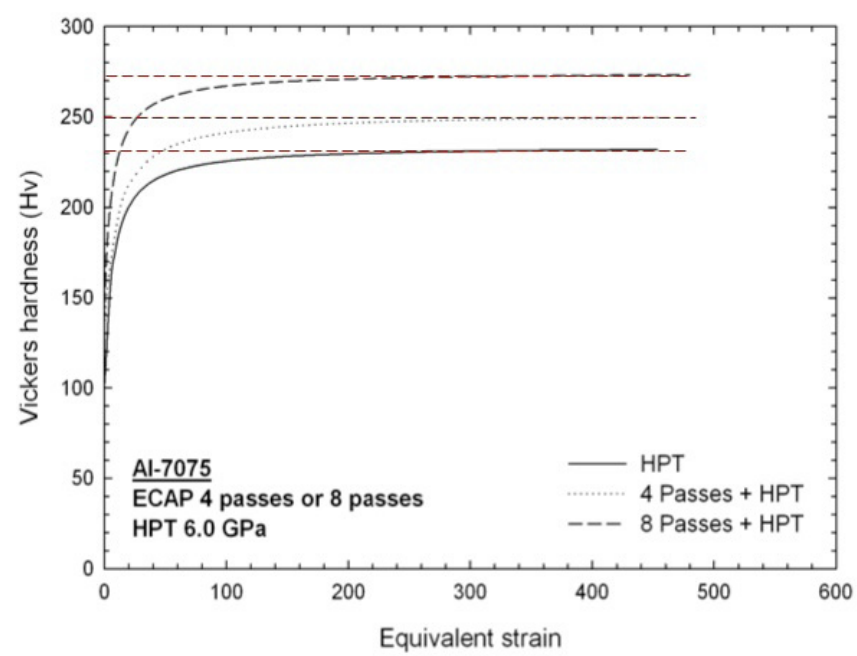

Fig. 5. Schematic illustration of Vickers microhardness against equivalent strain for samples processed by HPT, by ECAP for 4 passes + HPT and by ECAP for 8 passes + HPT. surements are the same across the diameters of each disk it is possible to simply average these measurements for each processing condition and then to plot the average value of the Vickers microhardness against the total numbers of turns in HPT as reported elsewhere [42]. This confirms that additional grain refinement, and therefore additional hardening, may be achieved by processing the material prior to HPT in order to achieve an even smaller initial grain size.

Mechanical testing shows that the alloy processed by ECAP for 8 passes and then HPT through 5 to 20 turns exhibits excellent superplastic properties with elongations up to and exceeding $1000 \%$. By contrast, superplastic elongations were not achieved in the alloy after ECAP through 8 passes without additional HPT even though the average grain size in this condition was measured as $\sim 600 \mathrm{~nm}$. Tensile specimens are usually cut from ECAP billets along the longitudinal axes corresponding to the $X$ direction but in this research the tensile specimens lay in the $X$ or cross-sectional plane. However, it is unlikely that this difference has any effect on the mechanical properties because it was established in earlier experiments that the mechanical behavior is essentially identical [43], including the superplastic properties [44], for specimens cut from the ECAP billets along each of the three basic orthogonal axes. The result also cannot be attributed to significant size differences between the ECAP and the ECAP+HPT specimens [45] because special care was taken to ensure that both sets of specimens were essentially identical in size. Therefore, the lack of superplastic behavior in the specimens processed only by ECAP, and the corresponding high levels of stress recorded in the stress-strain curves, must be due to the markedly non-uniform nature of the microstructure and the presence of many relatively large grains as visible in Fig. 1c and (e). It is apparent that the microstructures after processing by ECAP for 8 passes are not uniform and they consist of grains of various sizes in both the central and edge regions of the billet. This is in sharp contrast with the very uniform and equiaxed grains which are visible after processing by ECAP + HPT [28]. It is important to note also that the superplastic elongations after processing by ECAP for 8 passes + HPT are consistently higher than the elongations achieved in the same alloy after processing by ECAP for 4 passes + HPT or after processing only by HPT to 10 turns [28].

It is important to note that the initial microstructural condition prior to the two-step processing by ECAP+HPT is critical in order to demonstrate higher elongations, additional hardening and grain refinement. When materials are processed by HPT, most metals, including many face-centered cubic metals including Al-7075 alloy, exhibit a simple strain hardening behavior without any significant recovery [46]. However, some other materials exhibit different behavior including strain hardening with recovery in high-purity aluminum [22] and strain softening with respect to the initial condition in some two-phase alloys [47,48]. A full description of these various hardening models is given elsewhere [46]. However, additional experiments are now needed to determine whether these other materials also exhibit saturation hardness values, and minimum grain sizes, that vary depending upon the precise nature of the processing conditions as, for example, in processing using a combination of ECAP and HPT. 


\section{Summary and conclusions}

1. Experiments were conducted on an aluminum Al-7075 alloy to investigate hardness homogeneity and additional grain refinement during combinations of SPD processing.

2. Results on the Al-7075 alloy show that the saturation hardness is dependent upon the microstructural conditions within the material prior to processing. Higher values of saturation hardness are attained if the same material is processed by ECAP prior to HPT.

3. It is shown both by microstructural imaging and hardness measurements that additional grain refinement may be achieved in HPT by processing the material to produce an ultrafine-grain size before processing by HPT.

4. Lower flow stresses and significantly higher elongations to failure were observed in tensile testing after processing by ECAP for 8 passes + HPT. The elongations to failure were in the superplastic regime and exceeded $1000 \%$ at a testing temperature of $623 \mathrm{~K}$. Superplasticity was not achieved after processing only by ECAP because of the very non-uniform grain size.

Acknowledgements. This work was supported in part by the National Science Foundation of the United States under Grant No. DMR-1160966 and in part by the European Research Council under ERC Grant Agreement No. 267464-SPDMETALS.

\section{References}

1. E. O. Hall, J. Proc. Phys. Soc. B 64, 747 (1951).

2. N. J. Petch, J. Iron Steel Inst. 174, 25 (1953).

3. T. G. Langdon, Metall. Trans. 13A, 689 (1982).

4. R.Z. Valiev, R. K. Islamgaliev, I. V. Alexandrov, Prog. Mater. Sci. 45, 103 (2000).

5. R.Z. Valiev, Y. Estrin, Z. Horita, T.G. Langdon, M. J. Zehetbauer, Y. T. Zhu, JOM 58 (4), 33 (2006).

6. T. G. Langdon, Acta Mater. 61, 7035 (2013).

7. R.Z. Valiev, T. G. Langdon, Prog. Mater. Sci. 51, 881 (2006).

8. A.P. Zhilyaev, T.G. Langdon, Prog. Mater. Sci. 53, 893 (2008).

9. Y. Iwahashi, Z. Horita, M. Nemoto, T. G. Langdon, Acta Mater. 46, 3317 (1998).

10. S. Komura, Z. Horita, M. Nemoto, T. G. Langdon, J. Mater. Res. 14, 4044 (1999).

11. Y.H. Zhao, X.Z. Liao, Z. Jin, R.Z. Valiev, Y.T. Zhu, Acta Mater. 52, 4589 (2004).

12. M. Kawasaki, Z. Horita, T.G. Langdon, Mater. Sci. Eng. A524, 143 (2009).

13. J. Xu, M. Shirooyeh, J. Wongsa-Ngam, D. Shan, B. Guo, T. G. Langdon, Mater. Sci. Eng. A586, 108 (2013).

14. A. P. Zhilyaev, B. K. Kim, G. V. Nurislamova, M. D. Baró, J. A. Szpunar, T. G. Langdon, Scripta Mater. 46, 575 (2002).

15. A. P. Zhilyaev, G. V. Nurislamova, B. K. Kim, M. D. Baró, J. A. Szpunar, T. G. Langdon, Acta Mater. 51, 753 (2003).

16. J. Wongsa-Ngam, M. Kawasaki, T. G. Langdon, J. Mater. Sci. 48, 4653 (2013).

17. C. Xu, M. Furukawa, Z. Horita, T.G. Langdon, Mater. Sci. Eng. A398, 66 (2005).
18. C. Xu, K. Xia, T. G. Langdon, Acta Mater. 55, 2351 (2007).

19. J. Wongsa-Ngam, M. Kawasaki, T.G. Langdon, Mater. Sci. Eng. A556, 526 (2012).

20. M. Prell, C. Xu, T. G. Langdon, Mater. Sci. Eng. A480, 449 (2008).

21. A. Veveçka, M. Cabibbo, T. G. Langdon, Mater. Charact. 84, 126 (2013).

22. C. Xu, Z. Horita, T.G. Langdon, Acta Mater. 55, 203 (2007).

23. M. Kawasaki, R. B. Figueiredo, T. G. Langdon, Acta Mater. 59, 308 (2011).

24. M. Kawasaki, S. N. Alhajeri, C. Xu, T. G. Langdon, Mater. Sci. Eng. A529, 345 (2011).

25. R. Pippan, F. Wetscher, M. Hafok, A. Vorhauer, I. Sabirov, Adv. Eng. Mater. 8, 1046 (2006).

26. R. Pippan, S. Scheriau, A. Taylor, M. Hafok, A. Hohenwarter, A. Bachmaier, Ann. Rev. Mater. Res. 40, 319 (2010).

27. S. Sabbaghianrad, M. Kawasaki, T. G. Langdon, J. Mater. Sci. 47, 7789 (2012).

28. S. Sabbaghianrad, T. G. Langdon, Mater. Sci. Eng. A596, 52 (2014).

29. S. Sabbaghianrad, T. G. Langdon, Adv. Mater. Res. 922, 610 (2014).

30. Y. Iwahashi, J. Wang, Z. Horita, M. Nemoto, T. G. Langdon, Scripta Mater. 35, 143 (1996).

31. M. Furukawa, Y. Iwahashi, Z. Horita, M. Nemoto, T. G. Langdon, Mater. Sci. Eng. A257, 328 (1998).

32. K. Oh-ishi, Z. Horita, M. Furukawa, M. Nemoto, T. G. Langdon, Metall. Mater. Trans. 29A, 2011 (1998).

33. R. B. Figueiredo, P. R. Cetlin, T.G. Langdon, Mater. Sci. Eng. A528, 8198 (2011).

34. R. B. Figueiredo, P.H. R. Pereira, M.T. P. Aguilar, P. R. Cetlin, T. G. Langdon, Acta Mater. 60, 3190 (2012).

35. P.B. Berbon, M. Furukawa, Z. Horita, M. Nemoto, T. G. Langdon, Metall Mater Trans A 30A, 1989 (1999).

36. J.K. Mackenzie, M.J. Thomson, Biometrika 44, 205 (1957).

37. J. K. Mackenzie, Biometrika 45, 229 (1958).

38. T. G. Langdon, J. Mater. Sci. 44, 5998 (2009).

39. P. Serre, R. B. Figueiredo, N. Gao, T. G. Langdon, Mater. Sci. Eng. A528, 3601 (2011).

40. F. A. Mohamed, S.S. Dheda, Mater. Sci.Eng. A558:59 (2012).

41. F. A. Mohamed, S. S. Dheda, Mater. Sci. Eng. A580, 227 (2013).

42. S. Sabbaghianrad, J. Wongsa-Ngam, M. Kawasaki, T. G. Langdon, J. Mater. Res. Technol. 3, 319 (2014).

43. C. Xu, Z. Száraz, Z. Trojanová, P. Lukáč, T. G. Langdon, Mater. Sci. Eng. A497, 206 (2008).

44. G. Sakai, Z. Horita, T. G. Langdon, Mater. Trans. 45, 3079 (2004).

45. E. El-Danaf, M. Kawasaki, M. El-Rayes, M. Baig, J. A. Mohammed, T. G. Langdon, J. Mater. Sci. 49, 6597 (2014).

46. M. Kawasaki, J. Mater. Sci. 49,18 (2014).

47. M. Kawasaki, B. Ahn, T. G. Langdon, Acta Mater. 58, 919 (2010).

48. N.X. Zhang, M. Kawasaki, Y. Huang, T.G. Langdon, J. Mater. Sci. 48, 4582 (2013). 